\title{
PENGARUH DISIPLIN KERJA TERHADAP KINERJA KARYAWAN PADA PT. MEGA FINANCE CABANG KANDIS KABUPATEN SIAK
}

\author{
Saiful Anuar \\ Sekolah Tinggi Ilmu Ekonomi Riau \\ Jln. HR Subrantas KM 12 Telp (0761) 63237 Fax (0761) 63366 \\ E-mail : saiful.anuar40@yahoo.com
}

\begin{abstract}
The purpose of this study was to determine the influence of work discipline on employee performance at PT. Mega Finance Cabang Kandis Kabupaten Siak. The sample in this research is all employee at PT. Mega Finance Cabang Kandis Kabupaten Siak which amounts to 45 people. Sampling was conducted using a sample of saturated (Sugiyono, 2010:96) "sampling saturated sampling technique when all members of the population used as a sample". While the variables studied in this research is the discipline of work and performance.

Analysis of data using simple linear regression method using validity test, reliability test, normality, $t$ test and $R 2$. The tests are conducted to determine the relationship between the independent variables (independent variables) and dependent variable (dependent variable). Based on the results obtained value $R$ square at 0,711 which means that the discipline of work has contributed a donation of $71,1 \%$ to performance employees at PT. Mega Finance Cabang Kandis Kabupaten Siak. Partially acquired discipline of work variable positive and significant impact on the performance employees at PT. Mega Finance Cabang Kandis Kabupaten Siak with simple linear regression equation in this study $: Y=4,954+0,738 X$ significantly 0,000 smaller than alpha of 0.05. The final conclusion of this study that partial hypothesis between variables proven discipline of work to performance employees and can be accepted as true.
\end{abstract}

Keywords: Discipline of Work, Performance Employee.

\section{A. PENDAHULUAN}

Dalam sebuah perusahaan, untuk mencapai kinerja yang terbaik dibutuhkan karyawan-karyawan yang handal untuk mencapai target dan sasaran yang diinginkan oleh perusahaan. Karyawan-karyawan tersebut harus dapat bekerja sesuai dengan ketentuan yang telah ditetapkan oleh perusahaan. Tanpa mengikuti ketentuan tersebut, para karyawan tidak akan mungkin dapat bekerja sesuai dengan yang diinginkan oleh perusahaan.
Ketentuan yang ditetapkan oleh perusahaan biasanya telah sesuai dengan kebijakan yang telah diambil oleh perusahaan. Oleh sebab itu, setiap karyawan diharuskan melaksanakan kegiatan sehari-hari sesuai dengan kebijakan yang ditetapkan oleh perusahaan agar kinerja yang dihasilkan oleh karyawan dapat lebih maksimal. Kinerja merupakan hasil kerja yang dicapai oleh karyawan dalam melakukan tugas dan tanggung jawab yang diberikan oleh perusahaan kepadanya. Tanpa adanya kinerja yang dihasilkan oleh karyawan, perusahaan 
tidak akan dapat tumbuh dan berkembang dengan baik.

Salah satu cara meningkatkan kinerja karyawan adalah dengan menegakkan disiplin kerja karyawan. Disiplin merupakan sikap taat dan patuh karyawan terhadap ketentuan yang telah ditetapkan oleh perusahaan. Oleh sebab itu, disiplin merupakan pondasi awal untuk mencapai kinerja yang diinginkan oleh perusahaan.

Dari tabel dibawah ini dapat dilihat salah satu hasil kinerja yang dicapai oleh karyawan PT. Mega Finance Cabang Kandis dari tahun 2014-2018 :

\section{Tabel 1.2 Target Dan Realisasi Pembiayaan Sepeda Motor PT. Mega Finance Cabang Kandis Tahun 2014-2018}

\begin{tabular}{|c|c|c|c|}
\hline Tahun & $\begin{array}{c}\text { Target } \\
\text { (Unit) }\end{array}$ & $\begin{array}{c}\text { Realisasi } \\
\text { (Unit) }\end{array}$ & $\begin{array}{c}\text { Pencapaian } \\
(\boldsymbol{\%})\end{array}$ \\
\hline 2014 & 2.500 & 2.708 & $108,32 \%$ \\
\hline 2015 & 2.600 & 2.234 & $85,92 \%$ \\
\hline 2016 & 2.900 & 2.645 & $91,21 \%$ \\
\hline 2017 & 3.200 & 2.626 & $82,06 \%$ \\
\hline 2018 & 3.376 & 2.965 & $87,83 \%$ \\
\hline
\end{tabular}

Sumber : PT. Mega Finance Cabang Kandis, 2019.

Dari tabel 1.2 dapat dilihat pencapaian target yang dilakukan oleh karyawan pada PT. Mega Finance Cabang Kandis pada tahun 2014 mengalami peningkatan sebesar $108,32 \%$, pada tahun 2015 mengalami penurunan sebesar $85,92 \%$, pada tahun 2016 mengalami peningkatan sebesar 91,21\% sedangkan pada tahun 2017 mengalami penurunan sebesar $82,06 \%$ dan pada tahun 2018 mengalami peningkatan sebesar $87,83 \%$. Tidak tercapainya kinerja karyawan pada tahun 2018 diindikasi karena menurunnya disiplin kerja yang dilakukan oleh karyawan sehingga pekerjaan yang dilakukannya menjadi tidak maksimal.
Pekerjaan yang tidak maksimal dapat mengakibatkan penurunan kinerja perusahaan. Penurunan kinerja tersebut dapat dihindari apabila karyawan dapat bekerja secara disiplin sesuai dengan ketentuan yang diinginkan oleh perusahaan.

Berdasarkan uraian diatas terlihat betapa pentingnya peran disiplin kerja untuk meningkatkan kinerja karyawan. Adanya permasalahan tersebut maka penulis tertarik untuk melakukan penelitian dengan judul "Pengaruh Disiplin Kerja Terhadap Kinerja Karyawan Pada PT. Mega Finance Cabang Kandis Kabupaten Siak".

\section{Disiplin Kerja}

Menurut Sutrisno (2013:85) didalam kehidupan sehari-hari, dimanapun manusia berada dibutuhkan peraturan-peraturan dan ketentuanketentuan yang akan mengatur dan membatasi setiap kegiatan dan prilakuknya. Namun peraturan tersebut tidak akan ada artinya bila tidak disertai dengan sanksi bagi para pelanggarnya. Dalam bukunya yang berjudul Manajemen Sumber Daya Manusia, Sutrisno (2013:87) mengutip pendapat beberapa penulis asing tentang pengertian disiplin, pendapat-pendapat tersebut adalah sebagai berikut :

Terry, disiplin merupakan alat penggerak karyawan. Agar tiap pekerjaan dapat berjalan dengan lancar maka harus diusahakan agar ada disiplin yang baik. Terry kurang setuju jika disiplin hanya dihubungkan dengan halhal yang kurang menyenangkan (hukuman) karena sebenarnya hukuman merupakan alat paling akhir untuk menegakkan disiplin.

Menurut Singodimedjo dalam Sutrisno (2015:86) disiplin kerja adalah 
sikap kesediaan dan kerelaan seseorang untuk mematuhi dan menaati normanorma peraturan yang berlaku di sekitarnya. Sedangkan menurut Keith Davis dalam Mangkunegara (2011:129) berpendapat bahwa disiplin kerja dapat diartikan sebagai pelaksanaan manajemen untuk mempertahankan pedoman-pedoman organisasi.

Dari beberapa pendapat diatas dapat disimpulkan bahwa disiplin adalah bentuk pengendalian diri pegawai dan pelaksanaan kegiatan menajemen untuk menjalankan standarstandar organisasional. Tujuannya agar setiap pekerjaan dapat berjalan dengan lancar.

\section{Macam-Macam Disiplin Kerja}

Menurut T. Hani Handoko dalam Manik (2015:38), ada tiga bentuk disiplin kerja, yaitu :

1. Disiplin Preventif

Disiplin preventif adalah suatu upaya untuk menggerakkan pegawai mengikuti dan mematuhi pedoman kerja, aturan-aturan yang telah digariskan oleh perusahaan. Tujuannya adalah untuk menggerakkan pegawai berdisiplin diri.

\section{Disiplin Korektif}

Disiplin korektif adalah suatu upaya menggerakkan pegawai dalam menyatukan suatu peraturan dan mengarahkan untuk tetap mematuhi peraturan sesuai dengan pedoman yang berlaku pada perusahaan. Pada disiplin korektif, pegawai yang melanggar disiplin perlu diberikan sanksi sesuai dengan peraturan yang berlaku. Tujuan pemberian sanksi adalah untuk memperbaiki pelanggaran pegawai, memelihara peraturan yang berlaku dan memberikan pelajaran kepada pelanggar.
3. Disiplin Progresif

Disiplin progresif yaitu kegiatan memberikan hukuman-hukuman yang lebih berat terhadap pelanggaran-pelanggaran yang berulang. Tujuan disiplin progresif ini agar karyawan mengambil tindakan-tindakan korektif sebelum mendapatkan hukuman yang lebih serius.

\section{Faktor-Faktor Yang Mempengaruhi Disiplin Kerja}

Menurut Singodimedjo dalam Sutrisno (2014:89) ada beberapa faktor yang mempengaruhi disiplin kerja karyawan, yaitu :

1. Besar kecilnya pemberian kompensasi

Besar kecilnya pemberian kompensasi dapat mempengaruhi tegaknya disiplin, para karyawan akan mematuhi segala peraturan yang berlaku bila ia merasa mendapat jaminan balas jasa yang setimpal dengan balas jerih payahnya yang telah dikontribusikan bagi perusahaan.

2. Ada tidaknya keteladanan pemimpin dalam perusahaan.

Keteladanan pemimpin sangat penting sekali dalam menegakkan disiplin karyawan karena dalam lingkungan kerja semua pegawai akan selalu memperhatikan dan mengikuti bagaimana pemimpin menegakkan disiplin dirinya.

3. Ada tidaknya aturan yang pasti yang dapat dijadikan pegangan

Pembinaan disiplin tidak akan terlaksana dalam perusahaan, bila tidak ada aturan tertulis yang pasti untuk dapat dijadikan pegangan bersama.

4. Keberanian pimpinan dalam mengambil tindakan

Keberanian pimpinan untuk mengambil tindakan yang sesuai 
dengan tingkat pelanggaran yang dibuatnya.

5. Dalam setiap kegiatan yang dilakukan oleh perusahaan perlu ada pengawasan

Pengawasan tersebut dapat mengarahkan para karyawan agar dapat melaksanakan pekerjaan dengan tepat dan sesuai dengan yang telah ditetapkan.

6. Ada tidaknya perhatian kepada para karyawan

Karyawan tidak hanya puas dengan penerimaan kompensasi yang tinggi, pekerjaan yang menentang tetapi juga mereka masih membutuhkan perhatian yang besar dari pimpinanya sendiri.

\section{Pelaksanaan Sanksi Kedisiplinan}

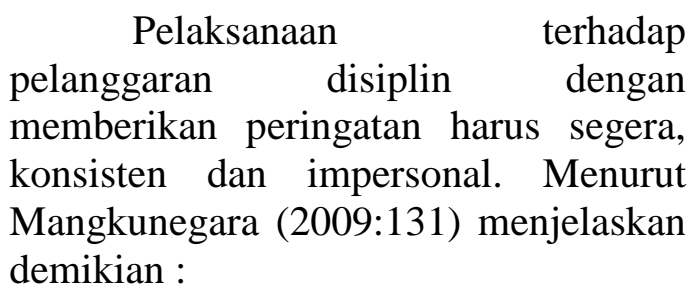

1. Pemberian peringatan

Karyawan yang melanggar disiplin kerja perlu diberikan surat peringatan pertama, kedua dan ketiga. Tujuan pemberian peringatan adalah agar para karyawan yang bersangkutan menyadari pelanggaran yang telah dilakukannya. Disamping itu pula surat peringatan tersebut dijadikan bahan pertimbangan dalam memberikan kondite karyawan.

2. Pemberian sanksi harus segera

Pegawai yang melanggar disiplin harus segera diberikan sanksi yang sesuai dengan peraturan organisasi yang berlaku. Tujuannya agar karyawan yang bersangkutan memahami sanksi pelanggaran yang berlaku diperusahaan.
Kelalaian pemberian sanksi akan memperlemah disiplin yang ada. Disamping itu, memberi peluang pelanggar untuk mengabaikan disiplin perusahaan.

3. Pemberian sanksi harus konsisten Pemberian sanksi kepada karyawan yang tidak disiplin harus konsisten. Hal ini bertujuan agar pegawai sadar dan mengahargai peraturanperataturan yang berlaku pada perusahaan. Ketidakkonsistenan pemberian sanksi dapat mengakibatkan karyawan mengadakan adanya diskriminasi karyawam, ringannya sanksi dan pengabaian disiplin.

4. Pemberian sanksi harus impersonal Pemberian sanksi pelanggaran disiplin harus tidak mebedabedakan karyawan, tua muda, priawanita tetap diperlakukan sama sesuai dengan peraturan yang berlaku. Tujuannya agar karyawan menyadari bahwa disiplin kerja berlaku untuk semua karyawan dengan sanksi pelanggaran sesuai dengan peraturan yang berlaku diperusahaan.

\section{Indikator Disiplin Kerja}

Menurut Singodimejo dalam Sutrisno (2011:94) indikator disiplin kerja adalah sebagai berikut :

1. Taat terhadap aturan waktu.

Dilihat dari jam masuk kerja, jam pulang dan jam istirahat yang tepat waktu sesuai dengan aturan yang berlaku di perusahaan.

2. Taat terhadap aturan perusahaan.

Peraturan dasar tentang cara berpakaian dan bertingkah laku dalam pekerjaan.

3. Taat terhadap aturan perilaku dalam pekerjaan.

Ditunjukkan dengan cara-cara melakukan pekerjaan-pekerjaan 
sesuai dengan jabatan, tugas dan tanggung jawab serta cara berhubungan dengan unit kerja lain.

4. Taat terhadap peraturan lainnya diperusahaan.

Aturan tentang apa yang boleh dan apa yang tidak boleh dilakukan oleh karyawan dalam perusahaan.

\section{Kinerja}

Menurut Anwar Prabu Mangkunegara (2011:67) pengertian kinerja (prestasi kerja) adalah hasil kerja secara kualitas dan kuantitas yang dicapai oleh seorang pegawai dalam melaksanakan tugasnya sesuai dengan tanggung jawab yang diberikan kepadanya. Prestasi kerja adalah suatu hasil kerja yang dicapai seseorang dalam melaksanakan, menyelesaikan pekerjaan yang dibebankan kepadanya. (Danang Sunyoto, 2012:18) Kinerja diartikan sebagai prestasi, menunjukkan suatu kegiatan atau perbuatan dan melaksanakan tugas yang dibebankan. Pengertian kinerja sering diidentikkan dengan prestasi kerja. (Supardi, 2013:45)

Kinerja menurut Nurmansyah (2010:177) berasal dari kata performance yang berarti hasil kerja secara kualitas dan kuantitas yang dicapai orang seorang karyawan dalam melaksanakan tugas sesuai dengan wewenang dan tanggung jawab yang diberikan kepadanya dalam batas waktu tertentu. Selanjutnya Nurmansyah (2010:177) juga menjelaskan bahwa secara sederhana, kinerja dapat juga diartikan sebagai bagian dari kontruksi yang diberikan oleh suatu departmen/divisi dalam pencapaian tujuan organisasi secara keseluruhan.

Selanjutnya Hasibuan dalam Yani (2012:117) mengemukakan kinerja adalah suatu hasil kerja yang dicapai seseorang dalam melaksanakan tugas-tugas yang dibebankan kepadanya yang didasarkan atas kecakapan, pengalaman dan kesungguhan serta waktu.Dengan kata lain bahwa kinerja adalah hasil kerja yang dicapai oleh seseorang dalam melaksanakan tugas yang diberikan kepadanya sesuai dengan kriteria yang ditetapkan.

\section{Tujuan Manajemen Kinerja}

Tujuan umum manajemen kinerja adalah untuk menciptakan budaya para individu dan kelompok memikul tanggung jawab bagi usaha peningkatan proses kerja dan kemampuan yang berkesinambungan. Secara khusus dan spesifik, manajemen kinerja bertujuan untuk (Surya Dharma, 2012:29)

1. Memperoleh peningkatan kinerja yang berkelanjutan.

2. Bertindak sebagai daya dongkrak untuk perubahan yang lebih berorientasi kinerja.

3. Meningkatkan motivasi dan komitmen karyawan.

4. Memungkinkan individu untuk mengembangkan kemampuan, meningkatkan kepuasan kerja dan mencapai potensi pribadi yang bermanfaat bagi individu dan organisasi.

5. Mengembangkan hubungan yang terbuka dan konstruktif antara individu dan manajer dalam suatu proses dialog yang berkesinambungan terkait dengan pekerjaan yang dilakukan sepanjang tahun.

6. Menyediakan suatu kerangka kerja bagi kesepakatan sasaran.

Faktor-Faktor Yang Mempengaruhi Kinerja

Menurut
(2011:67-68) faktor $\begin{array}{r}\text { Mangkunegara } \\ \text { yang }\end{array}$


mempengaruhi pencapaian kinerja, yaitu :

1. Faktor kemampuan (ability)

Secara psikologis, kemampuan (ability) pegawai terdiri dari kemampuan potensi (IQ) dan kemampuan reality (knowledge + skill) artinya pegawai yang memiliki IQ diatas rata-rata (IQ 110 - 120) dengan pendidikan yang memadai untuk jabatannya dan terampil dalam mengerjakan pekerjaan sehari-hari, maka ia akan lebih mudah mencapai kinerja yang diharapkan.

2. Faktor motivasi (motivation)

Motivasi terbentuk dari sikap (attitude) seorang pegawai dalam menghadapi situasi (situation) kerja. Motivasi merupakan kondisi yang menggerakan diri pegawai yang terarah untuk mencapai tujuan organisasi (tujuan kerja). Sikap mental seorang pegawai harus sikap mental yang siap secara psikofisik (siap secara mental, fisik, tujuan dan istimewa).

\section{Indikator Kinerja Karyawan}

Untuk memudahkan pengkajian kinerja karyawan, Mangkunegara (2011:75) mengemukakan indikatorindikator kinerja yaitu sebagai berikut :

1. Kualitas Kerja

Kualitas kerja terdiri dari ketepatan, ketelitian, keterampilan dan kebersihan karyawan dalam melakukan pekerjaan

2. Kuantitas

Kuantitas kerja terdiri dari output serta seberapa cepat bisa menyelesaikan pekerjaan yang diberikan oleh perusahaan.

3. Dapat Tidaknya Diandalkan

Terdiri dari seberapa besar karyawan bisa mengikuti instruksi, inisiati, hati-hati dan kerajinan karyawan dalam bekerja.

4. Sikap

Sikap terhadap perusahaan serta karyawan lainnya dalam melakukan pekerjaan serta kerjasama dalam menyelesaikan tugas yang diberikan.

\section{Pengaruh Disiplin Kerja Terhadap Kinerja}

Menurut Sutrisno

disiplin kerja pada karyawan (pegawai) sangat dibutuhkan karena apa yang menjadi tujuan perusahaan (organisasi) akan sukar dicapai bila tidak ada disiplin kerja. Dengan adanya disiplin kerja yang baik akan mempengaruhi dan menciptakan kondisi kerja yang baik untuk meningkatkan kinerja karyawan. (Anwar Prabu Mangkunegara, 2011:135) Kedisiplinan adalah kunci keberhasilan suatu organisasi dalam mencapai tujuannya. (Melayu S.P Hasibuan, 2012:193)

\section{METODELOGI PENELITIAN}

\section{Sumber Data}

\section{Data Primer}

Data Primer yaitu data yang langsung diperoleh dari objek penelitian. (Sugiyono, 2010:14) melalui wawancara dan kuisioner dengan pihak pimpinan dan karyawan pada PT. Mega Finance Cabang Kandis Kabupaten Siak.

\section{Data Sekunder}

Data skunder yaitu data yang penulis peroleh dan sumber data yang ada kaitannya dengan penelitian. (Sugiyono, 2010:14) Berupa data yang sudah tersedia seperti data jumlah karyawan, struktur organisasi dan data 
lainnya yang mendukung analisa dalam penelitian ini.

\section{Populasi dan Sampel}

\section{Populasi}

Populasi adalah keseluruhan subjek penelitian. Apabila seseorang ingin meneliti semua elemen yang ada dalam wilayah penelitian, maka penelitiannya merupakan penelitian populasi. (Arikunto, 2010:173) Penelitian ini dilakukan kepada seluruh karyawan pada PT. Mega Finance Cabang Kandis yang berjumlah 45 orang.

\section{Sampel}

Sampel adalah sebagian atau wakil populasi yang diteliti. Jika kita hanya akan meneliti sebagian dari populasi, maka penelitian tersebut disebut penelitian sampel. (Arikunto, 2010: 174) Sedangkan teknik pengambilan sampel ditentukan secara sensus yaitu mengambil seluruh populasi yang digunakan sebagai sampel karena jumlah populasi < 100 . Jadi sampel yang diambil dalam penelitian ini adalah seluruh karyawan pada PT. Mega Finance Cabang Kandis yang berjumlah 45 orang.

\section{Analisis Data}

Analisis data yang digunakan dalam penelitian ini adalah metode analisis menggunakan

a. Analisis deskriptif

yaitu suatu analisis dengan cara mengelompokan data yang disusun sedemikian rupa, kemudian menghubungkannya dengan teoriteori yang berkaitan dengan permasalahan yang dihadapi oleh perusahaan sehingga dapat diambil suatu kesimpulan. (Suharsimi Arikunto, 2010:282)

b. Metode kuantitatif adalah metode penelitian yang kemudian diolah dan di analisa untuk diambil kesimpulannya. (Suharsimi Arikunto, 2010:282)

\section{Uji Instrument Data}

Untuk menunjukan sejauh mana instrument penelitian dapat dipercaya dan dilakukan dengan dua pengamatan yaitu pengujian validitas dan reliabilitas dilakukan untuk mengukur apakah pertanyaanpertanyaan yang digunakan untuk mengukur indikator dalam kuisioner telah memenuhi persyaratan secara statistik atau tidak.

\section{HASIL PENELITIAN}

\section{Uji Validitas dan Reliabilitas}

Berdasarkan hasil uji validitas yang dilakukan pada penelitian ini, diperoleh hasil bahwa nilai $r$ hitung pada masing-masing variabel lebih besar dibandingkan dengan $r$ tabel 0,294 . Sedangkan untuk uji reliabilitas, diperoleh hasil nilai cronbach alpha, diperoleh hasil cronbach alpha untuk variabel Disiplin Kerja sebesar 0.942 dan Variabel Kinerja Karyawan sebesar 0.926 lebih besar dari 0.6. berdasarkan hasil uji validitas dan reliabilitas

\section{Regresi Linear Sederhana}

Berdasarkan data dari 45 orang responden, setelah dilakukan pengujian adapun persamaan regresinya adalah dengan menggunakan rumus SPSS. 17.0 didapat nilai $\mathrm{a}=4,954, \mathrm{~b}=0,738$, maka persamaan regresi linear sederhana adalah sebagai berikut :

$$
Y=4,954+0,738 X
$$


Berdasarkan persamaan di atas maka :

1. Konstanta 4,954. Berarti saat disiplin kerja diabaikan atau nol maka kinerja karyawan sebesar 4,954 satuan.

2. Koefisien variabel disiplin kerja (X) 0,738. Berarti jika variabel disiplin kerja di naikkan 1 satuan, maka kinerja karyawan PT. Mega Finance Cabang Kandis Kabupaten Siak akan naik sebesar 0,738 satuan. Koefisien variabel disiplin kerja bertanda positif. Berarti semakin baik disiplin kerja yang dilakukan karyawan maka kinerja karyawan pada PT. Mega Finance Cabang Kandis Kabupaten Siak akan ikut meningkat.

\section{Uji Hipotesis}

\section{Uji t}

Uji $t$ digunakan untuk mengetahui apakah variabel independen secara parsial berpengaruh positif dan signifikan terhadap variabel dependen. Untuk melihat hasil uji $\mathrm{t}$ dapat dilihat dari tabel 5.32 berikut ini :

Tabel 5.32 : Hasil Uji t

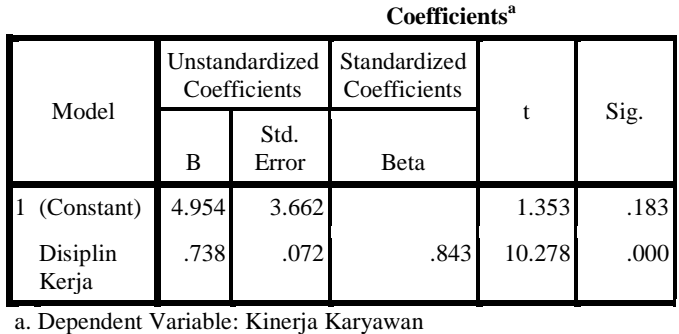

Sumber : Data Olahan SPSS. 17, 2019.

Dari tabel 5.32 dapat dilihat bahwa nilai $t_{\text {hitung }}$ disiplin kerja $(\mathrm{X})$ sebesar 10,278. Tingkat signifikan penelitian ini adalah 5\% atau 0,025 (Uji 2 sisi). Untuk melakukan uji t maka dilakukan langkah-langkah sebagai berikut : Tingkat signifikan penelitian ini adalah 5\% atau 0,025 (Uji 2 sisi). Berarti di dapat $t_{\text {tabel }}$ sebesar 2,017. Maka terbukti bahwa Disiplin kerja (X) $=$ dengan $t_{\text {hitung }} 10,278$ lebih besar dari $\mathrm{t}_{\text {tabel }}$ 2,017 dengan tingkat signifikan 0,000 lebih kecil dari 0,05. Maka Ho ditolak dan Ha diterima, artinya variabel disiplin kerja $(\mathrm{X})$ berpengaruh positif dan signifikan terhadap kinerja karyawan pada PT. Mega Finance Cabang Kandis Kabupaten Siak.

\section{Uji Koefisien Determinasi $\left(\mathbf{R}^{\mathbf{2}}\right)$}

Untuk mengetahui besarnya pengaruh disiplin kerja terhadap kinerja karyawan pada PT. Mega Finance Cabang Kandis Kabupaten Siak digunakan koefisien determinasi $\left(\mathrm{R}^{2}\right)$, setelah dilakukan pengolahan data dapat dilihat pada tabel 5.33 berikut ini :

\section{Tabel 5.33 : Hasil R -Square (Koefisien Determinan)}

\begin{tabular}{|l|r|r|r|r|}
\hline Model & $\mathrm{R}$ & $\begin{array}{c}\mathrm{R} \\
\text { Square }\end{array}$ & $\begin{array}{c}\text { Adjusted R } \\
\text { Square }\end{array}$ & $\begin{array}{c}\text { Std. Error of the } \\
\text { Estimate }\end{array}$ \\
\hline 1 & $.843^{\mathrm{a}}$ & .711 & .704 & 2.85090 \\
\hline
\end{tabular}
a. Predictors: (Constant), Disiplin Kerja
b. Dependent Variable: Kinerja Karyawan

Sumber : Data Olahan SPSS. 17, 2019.

Dari tabel 5.33 dapat diperoleh nilai $\mathrm{R} 0,843$. Hal ini berarti disiplin kerja secara simultan memiliki keeratan sebesar $84,3 \%$ terhadap kinerja karyawan sedangkan hasil nilai $r$ square (koefisien determinasi) sebesar 0,711. Hal ini berarti disiplin kerja memberikan sumbangan pengaruh terhadap kinerja karyawan pada PT. Mega Finance Cabang Kandis Kabupaten Siak sebesar $71,1 \%$ sedangkan sisanya sebesar $(100 \%$ $71,1 \%)=28,9 \%$ dipengaruhi oleh variabel lain diluar variabel dalam penelitian ini. 


\section{Kesimpulan dan Saran \\ Kesimpulan}

Berdasarkan hasil penelitian yang telah dilakukan mengenai pengaruh disiplin kerja terhadap kinerja karyawan pada PT. Mega Finance Cabang Kandis Kabupaten Siak, maka berikut ini penulis mengambil kesimpulan yaitu:

1. Hasil deskriptif tanggapan responden terhadap variabel disiplin kerja (X) adalah sangat setuju, variabel kinerja karyawan (Y) adalah sangat setuju.

2. Persamaan regresi linear sederhana adalah sebagai berikut :

$\mathrm{Y}=4,954+0,738 \mathrm{X}$. Berarti saat disiplin kerja diabaikan atau nol maka kinerja karyawan sebesar 4,954. Koefisien variabel disiplin kerja (X) 0,738. Berarti jika variabel disiplin kerja di naikkan 1 satuan, maka kinerja karyawan pada PT. Mega Finance Cabang Kandis Kabupaten Siak akan naik sebesar 0,738 satuan.

3. Disiplin kerja $(X)=$ dengan $t_{\text {hitung }}$ 10,278 lebih besar dari $t_{\text {tabel }} 2,017$ dengan tingkat signifikan 0,000 lebih kecil dari 0,05. Maka Ho diterima dan $\mathrm{Ha}$ ditolak, artinya variabel disiplin kerja (X) berpengaruh positif dan signifikan terhadap kinerja karyawan pada PT. Mega Finance Cabang Kandis Kabupaten Siak.

4. Nilai $r$ square (koefisien determinasi) sebesar 0,711. Hal ini berarti disiplin kerja memberikan sumbangan pengaruh terhadap kinerja karyawan pada PT. Mega Finance Cabang Kandis Kabupaten Siak sebesar $71,1 \%$ sedangkan sisanya sebesar $(100 \%-71,1 \%)=$ $28,9 \%$ dipengaruhi oleh variabel lain diluar variabel dalam penelitian ini.

\section{Saran}

Untuk meningkatkan kinerja karyawan pada PT. Mega Finance Cabang Kandis Kabupaten Siak agar lebih maksimal, disini penulis menyampaikan beberapa saran yaitu :

1. Diharapkan karyawan datang bekerja tepat waktu agar kinerja karyawan dapat meningkat.

2. Diharapkan kualitas kerja karyawan sesuai dengan syarat-syarat yang ditetapkan oleh perusahaan agar kinerja yang diharapkan oleh perusahaan dapat tercapai dengan maksimal.

3. Diharapkan karyawan memiliki keterampilan dalam bekerja agar kinerja yang dihasilkan dapat lebih meningkat.

4. Diharapkan karyawan mempunyai sikap yang baik dalam melakukan pekerjaan agar kinerja yang dihasilkan dapat lebih meningkat.

5. Diharapkan penelitian selanjutnya dapat diluar variabel dalam penelitian ini agar dapat menambah wawasan mengenai variabel lainnya. 


\section{DAFTAR PUSTAKA}

Arikunto, Suharsimi, 2010. Prosedur Penelitian, Edisi Revisi, Rineka Cipta, Jakarta.

Dharma Surya, 2012. Manajemen Kinerja, Cetakan V. Pustaka Pelajar, Yogyakarta.

Mangkunegara, A.A. Anwar Prabu, 2011. Manajemen Sumber Daya Manusia Perusahaan, PT. Remaja Rosdakarya, Bandung. , 2009. Manajemen Sumber Daya Manusia, PT. Remaja Rosdakarya, Bandung.

Manik, Sudarmin, 2015. Pengaruh Kepemimpinan, Motivasi Dan Disiplin Kerja Terhadap Kinerja Guru Madrasah Tsanawiyah Al-Huda Pekanbaru, Universitas Putra Indonesia "YPTK", Padang.

Nurmansyah. (2010). Manajemen Sumber Daya Manusia Strategik Untuk Meraih Keunggulan Kompetitif Perusahaa. Pekanbaru: Unilak Press.
Sugiyono, 2010. Metode Penelitian Administrasi, Cetakan XVIII, Alfabeta, Bandung.

Sunyoto, Danang, 2012. Teori Kuesioner Dan Analisa Data Sumber Daya Manusia, Cetakan I, CAPS, Yogyakarta.

Supardi, 2013. Kinerja Guru, PT. Raja Grafindo Persada, Jakarta.

Sutrisno, Edy, 2013. Budaya Organisasi, Kencana Prenada Media Group, Jakarta.

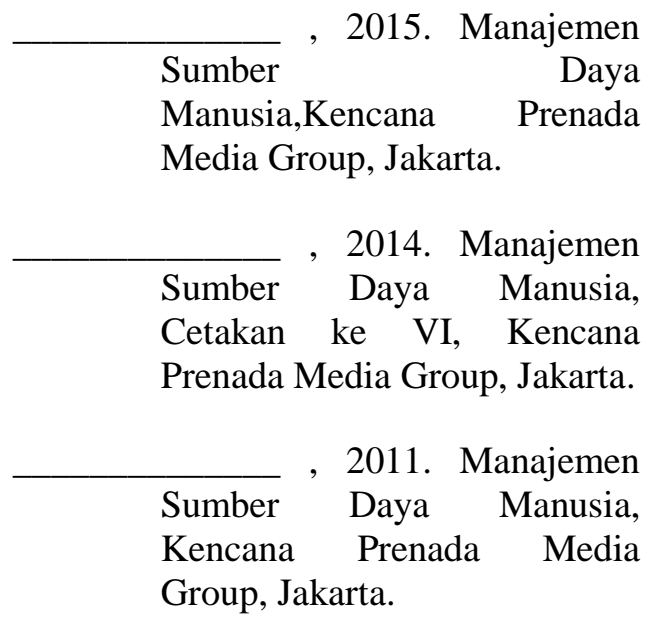

Yani, M, 2012, Manajemen Sumber Daya Manusia, Mitra Wacana Media, Jakarta 